\title{
APRENDER INGLÉS EN EL MUSEO: PROPUESTA DE TAREA TRASVERSAL PARA EL AULA DE INGLÉS DE ESO ${ }^{1}$
}

\author{
Gemma Delicado Puerto, Universidad de Extremadura \\ Email: gdelpue@unex.es
}

\begin{abstract}
Resumen: Esta tarea interdisciplinar muestra el potencial del patrimonio artístico, de museos y centros de interpretación como aulas abiertas para enseñanza/aprendizaje de lenguas y como elemento motivador para alumnado y profesorado. Como ejemplo práctico se presenta la explotación didáctica de un mito clásico, que funciona como antesala a la visita a Emerita Augusta (Mérida, España). Asimismo, se muestran ejercicios que tienen en cuenta competencias básicas y sus indicadores de evaluación. En definitiva, el proyecto se plantea para acercarse al arte y a la enseñanza de inglés como segunda lengua de forma novedosa, usando espacios fuera del aula tradicional y en colaboración con instituciones museísticas.
\end{abstract}

Palabras clave: arte, AICLE, TIC, historia, motivación, museo, tarea

Title in English: Learning English at the Museum: A Cross-Curricular Task Proposal for the Teaching of ESL in CSE

\begin{abstract}
This cross-curricular task illustrates how to exploit historic heritage, museums and interpretation centers as open classrooms for the teaching/learning of languages, in order to motivate teachers and students. As a practical example, the didactic use of a myth is presented to introduce the visit to the Roman town of Emerita Augusta (Mérida, Spain). In addition, specific exercises designed taking into account basic competencies and their evaluation criteria indicators are shown. This project has been created to approach art and English as a Second Language from a new perspective, using spaces outside traditional classrooms, and collaborating with museums.
\end{abstract}

Keywords: art, CLIL, ICTs, history, motivation, museum, task

\section{INTRODUCCIÓN}

En el marco de la adhesión al Espacio Europeo de Educación Superior es primordial encontrar nuevas metodologías que aúnen diferentes disciplinas para que el proceso de enseñanza/aprendizaje se realice globalmente. Por ello, este trabajo muestra una propuesta didáctica innovadora y multidisciplinar para la enseñanza de inglés como segunda lengua. La experiencia ha sido llevada a cabo en el Centro de profesores y recursos de Mérida en colaboración con profesorado de la Universidad de Extremadura durante los años 2011-2012 en el curso denominado "Teaching English through Art: Emerita Augusta as a

Date of reception: 24 April 2012

Date of acceptance: 24 October 2012 
Didactic Resource". En los talleres participaron un variado grupo de docentes de diferentes especialidades, quienes a lo largo de treinta horas de trabajo conocieron las posibilidades del patrimonio histórico y de los museos como espacios válidos para la enseñanza de segundas lenguas, en este caso concreto inglés. Posteriormente, algunos profesores que habían realizado el curso pusieron en práctica esta tarea con varios grupos de alumnos de $3^{\circ}$ y $4^{\circ}$ de ESO en dos centros de la Comunidad extremeña. Una vez concluida la experiencia y con el objetivo de comprobar el nivel de éxito del proyecto se pasaron encuestas de evaluación tanto a alumnos como a profesores participantes. Los resultados, que se muestran en el apartado seis de este trabajo, ofrecieron datos significativos favorables sobre su aplicación. A grandes rasgos, gracias a dichas encuestas se confirma algo que ya es manido, que los alumnos desarrollan mejor sus habilidades y, por ende, aumenta su interés por la materia y aprenden más rápidamente cuando se motiva a través de apropiadas metodologías de enseñanza.

Se ha de tener en cuenta que hasta hace pocos años en el aula de inglés se usaban métodos didácticos tradicionales con el Gramática-traducción como común denominador. En los últimos tiempos el enfoque comunicativo y la metodología de Aprendizaje Integrado de Contenidos y Lenguas Extranjeras (AICLE) van adquiriendo vital importancia, entre otras razones, gracias a la adhesión al Marco Común Europeo de Referencia para las Lenguas (MCERL) y la incorporación de las secciones bilingües en nuestro sistema. Sin embargo, a pesar de los avances en la enseñanza de inglés como segunda lengua y la implementación de nuevas metodologías, los resultados siguen siendo bastante pobres. Una de las razones de esta pobreza puede deberse a que los docentes se resisten a salir del aula y dichos enfoques se producen en un contexto ficticio. Recordemos que entre los objetivos de este método se encuentra el crear situaciones auténticas de comunicación, por lo que buscar aulas no tradicionales propicia esta autenticidad. El uso de contextos educacionales diferentes al aula cotidiana es más común en la metodología anglosajona ${ }^{2}$, que lo aplica desde edades tempranas ${ }^{3}$. Asimismo, también es característico de la enseñanza de Español como lengua extranjera (ELE), cuyas clases y seminarios suelen impartirse en espacios relacionados con la temática de los cursos ${ }^{4}$. No obstante, en la instrucción de enseñanza de inglés como segunda lengua en España resulta compleja, quizá por lo numeroso de las clases y lo estático de las programaciones. En otras palabras, es difícil romper tanto con la cuarta pared del aula como con los temas habituales al transmitir conocimientos básicos. A pesar de los avances seguimos centrados en contenidos gramaticales sin usar temas transversales ni contextos educativos innovadores. Paradójicamente, en programas bilingües de Primaria y Secundaria se contemplan este tipo de acciones desde áreas no lingüísticas donde la meta no es la lengua.

\footnotetext{
2 Véase web británica que propone enseñar fuera del aula tradicional: http://www.teachingoutsidetheclassroom.com/.

3 Véase programa para enseñanza de mitología en edades tempranas Roman Mythology for Kids:

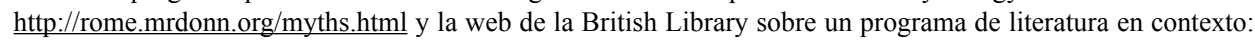
http://www.bl.uk/literatureincontext. En este sentido consúltese también la página de la British Broadcasting Corporation (BBC): http://www.bbc.co.uk/schools/primaryhistory/romans/city of rome/ y del Museo de Londres: http://www.museumoflondon.org.uk/learning/features facts/digging/

4 Véase un ejemplo sobre enseñanza de ELE en G. Delicado, "Taller de español a través de la literatura y cultura medievales".
} 
Entonces, ¿por qué no ampliar temas y contextos con un fin lingüístico? Para ello, este trabajo propone el uso de museos ${ }^{5}$ y del patrimonio artístico-histórico como aulas abiertas donde sus piezas funcionan como realia para contar historias de la Historia y para que la inmersión lingüística en contextos reales se convierta en herramienta para la adquisición de lenguas de un modo práctico, rápido y atractivo. Con respecto a la aprendizaje, recordemos que H. Gardner sostiene la existencia de varios tipos de inteligencia (espacial, musical, cinésica, interpersonal, intrapersonal, lingüística y lógico-matemática) (H. Gardner 1999 y 2004). A su vez, L. Knowles, distingue hasta cuatro estilos de aprendizaje: el concreto, el analítico, el comunicativo y el basado en la autoridad (Knowles 1982). Teniendo en cuenta estas teorías los alumnos pueden elegir entre diversos estilos en función del contexto de aprendizaje, lo cual demuestra que los estilos no son inmutables y fijos, sino flexibles y cambiantes. Esto quiere decir que el aprendizaje de idiomas de los alumnos se verá favorecido con la variedad de actividades y espacios para aprender que se les proponga (Reid 1995). Es por ello que, el dinamismo que ofrece esta propuesta enmarcada en un paisaje nuevo, abierto y motivador, pretende estimular las capacidades cognitivas de los estudiantes.

Con este método, además de potenciar la competencia lingüística en lengua inglesa, se busca ampliar conocimientos sobre el patrimonio para así favorecer el desarrollo de una actitud sensible hacia esta herencia cultural. El proyecto se nutre de las tecnologías de la información y la comunicación, posibilidades que lo enriquecen aunando la historia, el arte, la lengua y la técnica digital. Es decir, la fusión de lo nuevo y lo antiguo para motivar el aprendizaje. De la misma forma, su gran componente visual, táctil y práctico pretende mostrar cómo incentivar a los alumnos, ayudarles a mejorar las cuatro destrezas y, en concreto, facilitar pautas para empezar a narrar y describir apoyándose en la construcción de una base léxica sólida. Aprender o mejorar una lengua a través del arte, no solo ayuda a los alumnos a poner en práctica estructuras gramaticales, sino que fomenta su creatividad, cualidad que es de suma importancia a la hora de expresarse en otro idioma.

En definitiva, esta propuesta ha sido diseñada para que, siguiendo el esquema básico ofrecido $^{6}$, con creatividad y colaboración entre áreas pueda adaptarse a cualquier museo o centro de interpretación. De este modo se brinda a profesores y alumnos la posibilidad de analizar y conocer su entorno con la lengua inglesa como vehículo y fin.

\section{OBJETIVOS DE LA TAREA DESGLOSADOS POR COMPETENCIAS ${ }^{7}$}

1. Competencia lingüística. $\mathrm{C} 1$.

2. Competencia en el conocimiento y uso de las TIC. C4.

3. Competencia cívica y social. C5.

4. Competencia cultural y artística. C6.

\footnotetext{
Sobre las ventajas de la enseñanza en museos, consúltese E. Hooper-Greenhill. Museums and Education. Purpose, Pedagogy, Performance y G.H.Hein. Learning in the Museum.

6 Véase esquema en la sección 5.1 de este trabajo.

7 Basado en Common European Framework of Reference for Languages: Learning, Teaching, Assessment. Strasbourg: Council of Europe y en RD83/2007, de 24 de abril. DOE 0/05/2005, n ${ }^{\circ} 51$ Currículo de Educación Secundaria Obligatoria para la Comunidad Autónoma de Extremadura, Junta de Extremadura, Consejería de Educación. Asimismo, se ha consultado, C. Coll, Las competencias básicas en educación.
} 
5. Competencia para aprender a aprender. C7.

\subsection{Competencia lingüística}

- Estimular a los alumnos a que escuchen y se expresen en inglés en clase, pero también fuera del aula (escuchar, repetir, explicar, resumir y describir en torno a la temática del mito o la pieza de arte), con el fin de prepararles para comunicarse en situaciones reales.

- Animar a los alumnos a que pierdan el miedo a expresarse en otra lengua teniendo en cuenta el cambio de contexto del aula.

- Construir y asimilar un corpus de una manera rápida mediante cognados.

- Comprender el argumento general y pequeños detalles de los mitos y las historias de la Historia que se presentan.

- Ser capaz de completar los mitos/historias que se trabajan en el taller.

- Ser capaz de ofrecer nuevos finales de manera oral y escrita a los mitos.

- Motivar a los alumnos a describir a otras personas (mediante piezas de arte).

- Aprender que la lengua inglesa es una lengua franca que sirve para comunicar con cualquier persona y sobre cualquier tema.

\subsubsection{Objeticos lingüisticos específicos de la tarea}

- Aprender el vocabulario específico de un mito relacionado con la creación del mundo y el universo.

- Explorar algunas costumbres de los antiguos romanos y el vocabulario relacionado con adaptaciones de textos clásicos.

- Reforzar el uso del pasado simple.

- Practicar y perfeccionar las pautas para narrar historias y describir personas.

\subsection{Competencia en el conocimiento y uso de las TIC}

- Fusionar las nuevas tecnologías con áreas tradicionales como la historia y la literatura.

- Discriminar información específica en Internet.

\subsection{Competencia cívica y social:}

- Fomentar el interés por el patrimonio cultural y artístico local y nacional. 
- Apreciar y valorar la historia como vehículo de trasmisión de valores.

- Fomentar la colaboración entre áreas de conocimiento.

\subsection{Competencia artístico-cultural}

- Animar la creatividad del profesorado de ESO.

- Promover la creatividad del alumno mediante el contacto con literatura y obras de arte.

- Aprender vocabulario y gramática de una manera más atractiva y en contextos no tradicionales.

\subsection{Competencia para aprender a aprender:}

- Trabajos de campo (tradicionales y digitales).

- Enseñar a afianzar la información mediante recursos tradicionales y digitales.

- Fomento del pensamiento crítico a través de cazas del tesoro, juegos de vocabulario, de identificación, asociación, storytelling, etc.).

- Asimilar que podemos aprender historia, arte y una lengua extranjera mientras nos divertimos.

- El profesorado colabora con instituciones fuera del ámbito docente.

\section{MATERIALES Y TECNOLOGÍA}

Durante las sesiones se usarán manuales de realización propia. Además, dichos materiales se complementarán con recursos web. Ambos se muestran en el blog titulado: http://eslinthemuseum.blogspot.com.es/

\section{CRITERIOS DE EVALUACIÓN}

Para evaluar las actividades se tendrán en cuenta el desarrollo positivo de las cuatro destrezas, presentes en la mayoría de los ejercicios, en conjunto con los indicadores de evaluación correspondientes a cada competencia y subdimensión mediante una rúbrica. Dicha rúbrica se entregará al principio de la Fase A para que cada alumno sea consciente de los objetivos que debe alcanzar. Esta herramienta proporciona a los alumnos una visión clara de lo que deben hacer para lograr los objetivos establecidos. De esta manera no solo se facilita la evaluación por parte del profesor, sino que también se abre la puerta a la autoevaluación. ${ }^{8}$

\footnotetext{
8 La rúbrica se incluye en la Fase C o sección de evaluación y resultados.
} 


\section{ORGANIZACIÓN DE LA PROPUESTA Y TEMPORALIZACIÓN}

La propuesta se divide en tres fases diferenciadas: la A que consta de cuatro sesiones donde se contextualizan los mitos dentro del Imperio Romano y al mismo tiempo sirve de preparación a la visita al museo; la $\mathrm{B}$ donde se visita el museo y se pone en práctica todo lo aprendido; en la $\mathrm{C}$ se procederá a la evaluación de la adquisición de conocimientos de los alumnos y de la viabilidad del proyecto. Seguidamente se ofrece un resumen de dichas fases divididas por sesiones en las que se incluyen las actividades diseñadas específicamente para la comprensión de esta tarea.

\subsection{Esquema para aplicar el proyecto en cualquier museo o centro de interpretación}

- Estudiar detalladamente contenido del museo o centro de interpretación para establecer las fases A, B y C.

- Fijar la época que se quiere estudiar y conectarla con un mito o leyenda.

- Adaptar el mito o leyenda al nivel de los alumnos para hacer más sencilla su comprensión. Desglosarlo por partes para el ejercicio de storytelling.

- Presentar, en la medida de lo posible, el vocabulario mediante un corpus basado en un contexto cercano y en cognados. Se pueden usar fotos, mural tradicional o Power Point.

- Ofrecer ejercicios relacionados con el mito para aprender vocabulario y conseguir una meta gramatical conectada con el currículo9 y nivel del curso.

- En la medida de lo posible, relacionar el mito o leyenda con una pieza del museo para vincular la historia con la visita. Después se puede contar el mito junto a la pieza.

- Preparar la visita al museo (incluir mapa del museo con leyendas en inglés, relectura del mito, Scavenger hunt, descripción de las piezas, invención de alguna historia relacionada con las obras y toma de fotografías para plasmar ejercicio de extensión).

- Fomentar el interés por el patrimonio cultural y artístico local y universal.

- Analizar los resultados de aprendizaje obtenidos a través de rúbrica.

- Analizar el interés y éxito de la actividad para el alumnado mediante encuestas.

\section{FASE A:}

A grandes rasgos, en este proyecto se pretende contextualizar los mitos ${ }^{10}$ dentro del periodo que abarcó el Imperio Romano con el fin de que los alumnos puedan percibir cómo

\footnotetext{
$9 \quad$ Basado en REAL DECRETO 83/2007, de 24 de abril. DOE 05/05/2007 $n^{\circ} 51$ por el que se establece el Currículo de Educación Secundaria Obligatoria para la Comunidad Autónoma de Extremadura, Junta de Extremadura, Consejería de Educación. 7980-8152.

10 A la hora de diseñar estrategias para contar el mito se ha tenido en cuenta a R. Carter "Linguistic Models, Language, and Literariness: Study Strategies in the Teaching of Literature to Foreign Students.” También se ha consultado C. Savvidou "An Integrated Approach to Teaching Literature in the EFL Classroom."
} 
la arquitectura, arte, cultura, tradiciones, dieta, etc. han sido influidos por nuestros ancestros los romanos. Teniendo en cuenta que las versiones originales de los mitos tendrían una dificultad alta para el alumnado, se proponen adaptaciones de los mismos pensadas para la edad y el nivel general de los estudiantes. De este modo, antes de leer se explica que los mitos han sufrido diferentes versiones y adaptaciones a lo largo de los siglos y la que se va a trabajar sería una más de la cadena.

Como presentación de esta fase vamos a analizar un mito que nos hará explorar el vocabulario y las costumbres de los dioses de la antigüedad clásica. En general, e independientemente de la edad, a los jóvenes les encanta que les cuenten historias, "most children of any age love to hear and read myths, and even to write their own myths. The stories of the gods and goddesses seem to have a particular appeal for their imaginations. They become fascinated with the exploits of the gods" (Doyle, 2012). Las historias que más suelen atraer en Primaria son las que tienen componentes de aventuras, fantasía y magia. Sin embargo, en $3^{\circ}$ y $4^{\circ}$ de ESO, con 15-16 años, los adolescentes se vuelven más atrevidos, y a esta edad les dejan de interesar princesas y príncipes y les fascinan los dioses guerreros, aventureros, incluso los relatos cruentos. Estos ingredientes se encuentran en los mitos, que son historias universales con un patrón común en los que las deidades del Olimpo representan a reyes y reinas, héroes y villanos con sus tramas y guerras particulares. Por su estructura narrativa y sus cortas dimensiones son adaptables para leerlos en una sesión de clase. Estos elementos también se hallan en el mito usado en esta propuesta.

Según el currículo actual, la asignatura de arte no se ofrece en la ESO como materia obligatoria, sino como optativa. Esto significa que para innumerables alumnos los conceptos sobre arte se presentarán como algo nuevo. Para solventar esta carencia y apremiar el aprendizaje se usarán ejercicios basados en cognados, términos con una misma etimología, pero con distinta evolución fonética (Nash 1999). Es decir, son palabras que tienen parientes entre sus antepasados. Precisamente, entre el castellano y la lengua inglesa se producen cuantiosos en aquellos términos que en ambas lenguas proceden del latín o el griego. De hecho, aunque las clases de historia de la lengua se reducen al ámbito universitario, otra manera de motivar a los alumnos consiste en explicarles que los hablantes de castellano compartimos el 50\% del vocabulario de los angloparlantes. Se ha destacar que en la enseñanza ELE, sobre todo en los EE.UU, se usan los cognados en las etapas iniciales del aprendizaje para así acelerar la adquisición de la lengua. Por todo ello, si contextualizamos los mitos en la época romana podemos ilustrar el vocabulario a través de la gran variedad de cognados existentes y de ese modo construir un corpus lingüístico de una manera rápida y eficaz. Igualmente, la capacidad comprensiva de los alumnos a la hora de leer aumentará a medida que crezca su corpus semántico.

\section{Session I: THE MYTH OF SEASONS}

Se prepara al alumnado para aprender un mito.

Objetivos: Al presentar el mito El origen de las estaciones por etapas los alumnos amplían su vocabulario. 
Gramaticalmente practican el pasado simple, tiempo verbal que les ayuda a hilar la estructura narrativa. Se fomenta el gusto por la lectura y en concreto por la lectura de mitos. Se les inicia en el arte de la narración ${ }^{11}$.

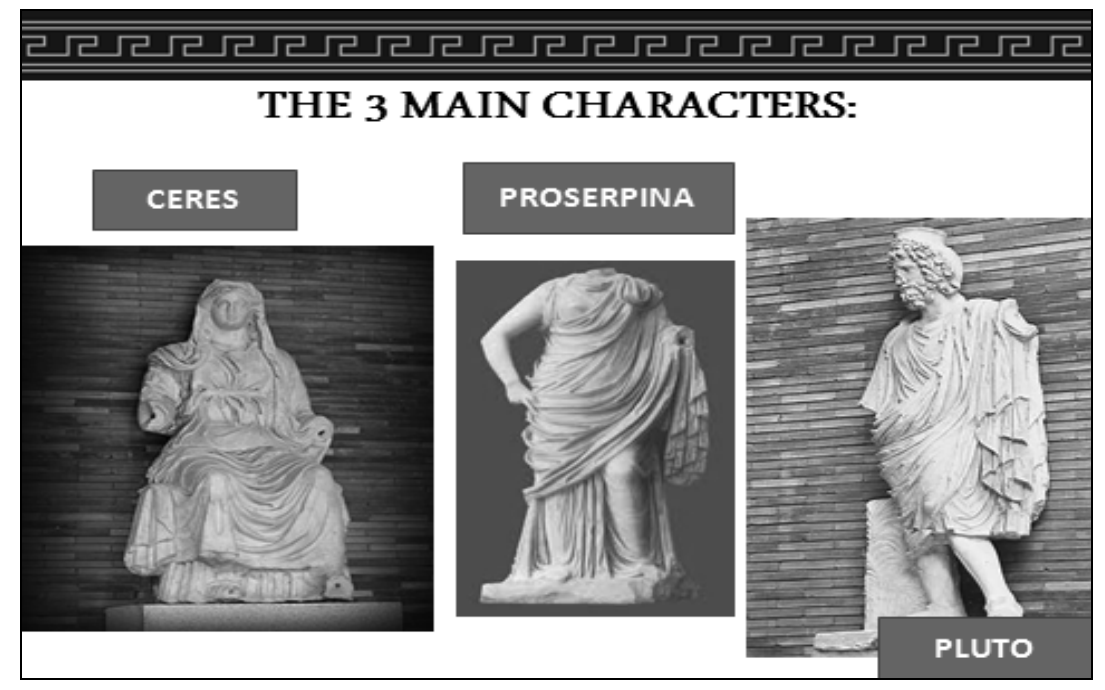

Preparación de la sesión: Después de una breve introducción a la cultura romana, el profesor ofrece una lista de aquellos nombres de dioses del Olimpo más relevantes para la comprensión del mito El origen de las estaciones:

Activity I.1: Read and learn the most important gods and goddesses in the Olympus.

SOME ROMAN GODS AND GODDESSES
Cupid - the god of love
Ceres- the goddess of agriculture
Diana - the goddess of the moon and hunting
Juno - Jupiter's wife, goddess of women
Jupiter - king of the gods (Zeus, ruler of the Greek Gods and Mount Olympus)
Mars - the god of war (Ares in Greek mythology)
Mercury- the messenger of the gods and god of commerce, travel and thievery
Neptune - the god of the sea
Pluto- the god of the underworld
Saturn- God of agriculture (Chronus, time God in Greek mythology)
Uranus- is the ancient Greek God of the Heavens
Venus - the goddess of love and beauty (Aphrodite in Greek mythology) ${ }^{2}$

11 Las imágenes usadas son privadas o extraídas de webs que permiten su difusión. Pueden encontrase este tipo de imágenes en Clip Art: http://etc.usf.edu/clipart/galleries/Arts/roman ornament.php

También puede consultarse Artcyclopedia: http://www.artcyclopedia.com, y el banco de imágenes y sonidos del Ministerio de Educación, cultura y deporte: http://recursostic.educacion.es/bancoimagenes/web/ 
Para enriquecer y asimilar la actividad se puede usar el catálogo de dioses en un cartel de colores tradicional o Power Point. A través de una lectura se explica la relación entre los dioses del Olimpo con los planetas de nuestro sistema solar:

Activity I.2: Read and write about our solar system. Complete the text with the words in the box ${ }^{12}$.

\begin{tabular}{|lrcccc|}
\hline Mars & Sun & Venus & Uranus & Jupiter & Pluto \\
Mercury & Saturn & & Earth & Neptune & \\
\hline
\end{tabular}

Discovering our Solar System through Ancient Roman Gods and Goddesses

In our solar system, nine planets move around the (1). He was a sky deity. The closest planet to the Sun is (2). Romans considered this divinity the god of commerce, travel and thievery. In Greek mythology, he was known as the messenger of Gods. Probably, its name originated in the fact that it moves very quickly around the Sun. was the Roman god of war. It is also referred to as the red planet. (4) was considered the king of the Roman gods and goddesses and also the ruler of the Roman state. According to Greek mythology he was known as Zeus, the ruler of the Greek gods and the mount Olympus. (5) was the Roman God of agriculture. In Greek mythology he was known as Cronus. He is Jupiter's father. In Roman, mythology, (6) was the goddess of love and beauty. In Greece, her name was Aphrodite. The (7) is the fifth largest planet in our solar system. It is also known as the blue planet. It is seen as a fertile goddess . (8) was the Lord of the skies and the husband of Earth. (9) is not considered a planet anymore. In Roman mythology he was the ruler of the underworld and kidnapped Proserpina, Ceres's daughter. (10) is the god of sea and water.

Por medio de un breve quizz se completa una tabla con la deidad, y se especifica el género, si es dios o diosa y de qué son divinidades:

Activity I.3: Complete the chart with the genre of the god, specifying the word god (for male deities) or goddess (for female deities) and also say of what he or she is a deity ${ }^{13}$.

\begin{tabular}{|l|l|l|}
\hline Name & God/Goddess & Deity of... \\
\hline Sun & God & sky \\
\hline & & \\
\hline
\end{tabular}

12 Key: Sun, Mercury, Mars, Jupiter, Saturn, Venus, Earth, Uranus, Pluto, Neptune.

13 Key: Sun, Mercury, Mars, Jupiter, Saturn, Venus, Earth, Uranus, Pluto, Neptune.

\begin{tabular}{|l|l|l|}
\hline Name & God/Goddess (gender) & Deity of ... \\
\hline Sun & God & sky \\
\hline Mercury & God & commerce, travel and thievery \\
\hline Mars & God & war \\
\hline Jupiter & God & king of Roman gods and goddesses; ruler of the Roman state \\
\hline Saturn & God & agriculture \\
\hline Venus & Goddess & love and beauty \\
\hline Earth & Goddess & fertility \\
\hline Uranus & God & skies; and the husband of Earth \\
\hline Pluto & God & ruler of the underworld \\
\hline Neptune & God & sea and water \\
\hline
\end{tabular}


Después de haber completado el texto anterior se pide al alumno que relacione mediante flechas los días de la semana y los nombres de los dioses, de esta manera quedarán unidos a palabras más familiares:

Activity I.4: Connect with arrows days of the week and gods and goddesses. A hint: three gods are Roman and the rest are Nordic deities ${ }^{14}$.

\begin{tabular}{|ll|}
\hline Monday & Moon \\
Tuesday & Sun \\
Thednesday & Saturn \\
Friday & Tiw \\
Saturday & Woden \\
Sunday & Thor \\
\hline
\end{tabular}

Para terminar, afianzamos la información mostrada en la sesión I por medio de un quizz donde además practicamos verbos relacionados con los planetas:

Activity I.5: Mythology Quizz, please circle the right answers ${ }^{15}$.

\section{Mythology Quizz. Pre-visit activities:}

\section{Ruler of the underworld:}

a. Poseidon b. Zeus c. Pluto d. Hades

\section{Roman goddess of agriculture:}

a. Vesta b. Vulcan c. Mars d. Ceres

\section{This girl was Ceres's daughter:}

a. Vesta b. Aphrodite c. Hera d.Proserpina

\section{This god is the god of time:}

a. Hades b. Hermes c. Apollo d. Chronus

\section{Beautiful and goddess of love:}

a. Aphrodite b. Hera c. Venus d.Athena

6. He is the god of the sea:

a. Minerva b. Vesta c. Mars d. Pluto

7. The most powerful of gods:

a. Poseidon b. Jupiter c. Apollo d. Pluto

8. The god of love was:

a. Cupid b. Hephaestus c. Pluto d.Saturn

Se trabaja por competencias y se evalúan subdimensiones mediante rúbrica:

I.1 (C1, C6, (C4)); I.2 (C1, C6); I.3 (C1, C6); I.4 (C1, C6); I.5 (C1, C6)

14 Key: Monday-Moon; Tuesday-Tiw; Wednesday-Woden; Thursday-Thor; Friday-Freya; Saturday-Saturn; Sunday-Sun.

15 Key: 1C, 2D, 3D, 4D, 5C, 6C, 7B, 8A. 


\section{Session II: USING COGNATES}

Se utiliza un corpus basado en un contexto cercano y en cognados.

Objetivos: conocidos los nombres de los dioses y sus características, se procederá a mostrar alguna de las escenas del mito, todo ello para facilitar la comprensión de la historia. De entre los nombres de los dioses destacamos a los protagonistas. Seguimos afianzando los nombres de los dioses y el uso del pasado simple.

Preparación de la sesión: Se presentará el vocabulario relevante del mito en Power Point y/o mediante el mapa de bits. Además, recordamos los nombres de los dioses principales de este mito por medio del mapa de bits:

Activity II.1: Draw a family tree with the main characters from the Origins of the season's myth. Pedimos a los alumnos que dibujen un family tree inspirándose en las fotos que mostramos en el ejercicio anterior (THE 3 MAIN CHARACTERS: CERES: the mother (Queen); PROSERPINA: The daughter (Princess); PLUTO: GOD of the UNDERWORLD (Prince of the underworld and warrior):

Activity II.2: Read, repeat and identify the vocabulary of the myth: The origin of seasons. Tras la fase preparatoria el profesor cuenta el mito muy despacio con la ayuda de dibujos y gestos. Más tarde los alumnos pueden ayudar a completar la historia:

Activity II.3: Now, we tell the myth. Then, you act it out!

\section{The Origin of Seasons}

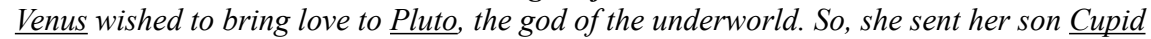
to hit him with one arrow. Pluto, fell madly in love with Proserpina and abducted the young and beautiful girl to marry and live with him.

Ceres, the goddess of agriculture, was Proserpina's mother. Worried about the situation, she asked Jupiter for help. Jupiter sent Mercury to order Pluto to free Proserpina. Pluto obeyed, but before letting her go, he made her eat six pomegranate seeds. However, those who eat the food of the dead cannot return to the world. This meant that she would have to live six months of each year with Pluto in the underworld, and stay the rest of the months with her mother Ceres on Earth.

In her sadness, Ceres furiously stopped the growth of fruits, cereal and vegetables on Earth while her daughter stayed in the underworld with Pluto. Finally, when Ceres welcomed Proserpina back on Earth, trees and plants blossomed, and spring and summer came. When Proserpina returned with her husband to the underworld they withered again. So, for ancient Romans, this story explained the changing of the seasons.

Después se analizará el texto y colocarán las palabras por categorías. El objetivo gramatical es que completen con pasado simple:

Activity II.4: Complete the chart with the past simple forms from the text ${ }^{16}$ :

\begin{tabular}{|c|}
\hline Past simple \\
\hline Wanted \\
$\ldots$ \\
\hline
\end{tabular}

${ }_{16}$ Key: wished, sent, fell, abducted, was, worried, asked, sent, obeyed, made, meant, stopped, stayed, welcomed, blossomed, returned, withered, explained. 
Para concluir la sesión, en la actividad 5, se lee el mito y se completa el ejercicio denominado "Familias de opuestos":

Activity II.5: Look at the box, and decide which the opposites are.

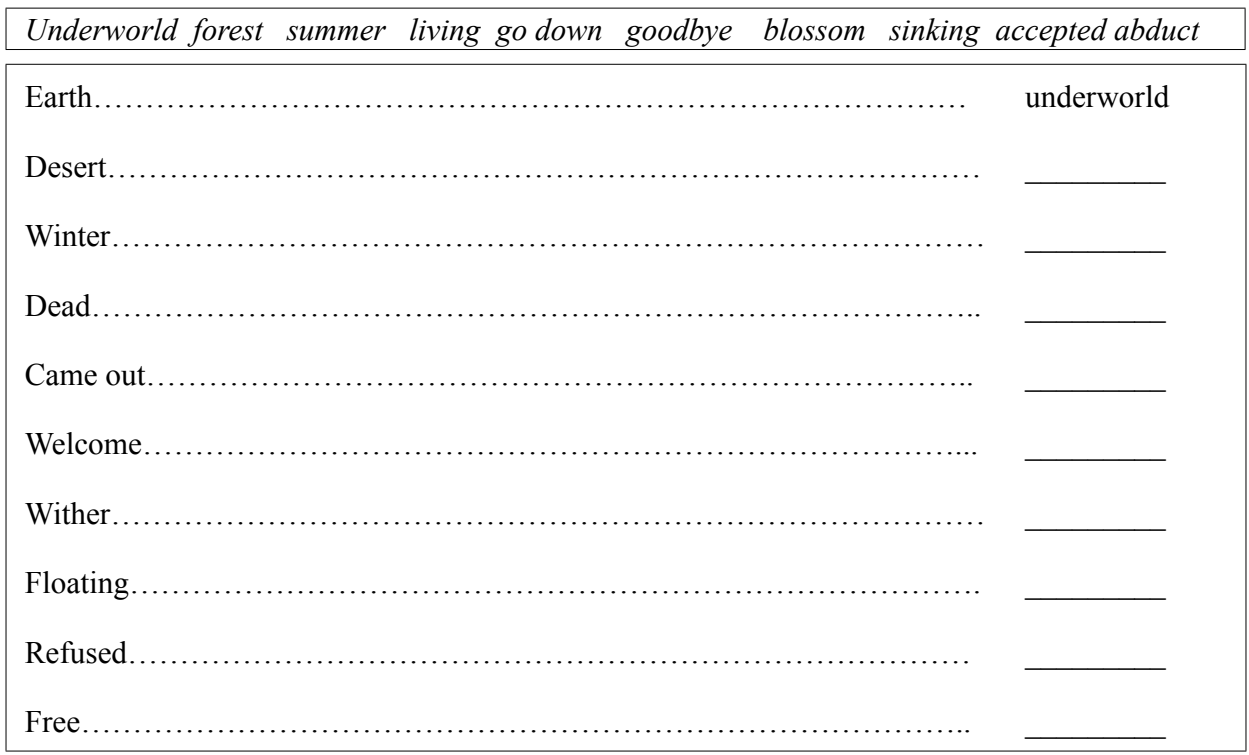

Se trabaja por competencias y se evalúan subdimensiones mediante rúbrica: C6, C7).

II.1 (C1, C6, C4); II.2 (C1, C6, C4, C7); II.3 (C1, C6, C7); II.4 (C1, C6, C7); II.5 (C1,

\section{Session III (Preparación visita). AT THEIR LEISURE AND SPARE TIME}

Se presentan algunas costumbres de los romanos.

Objetivos: Durante la sesión III se trabajará usando cognados el vocabulario específico relacionado con los objetos y lugares que se conocerán durante la visita al museo. Gramaticalmente se seguirá practicando el pasado simple para formular frases en las que se describen las acciones y costumbres de los romanos. Además de introducir el arte de narrar, se trabaja la descripción. Ambas cuestiones se ponen en práctica en la sesión IV.

Preparación de la sesión: En general, la visita al museo también se prepara haciendo uso de los cognados. Se presenta el vocabulario del tiempo libre y el ocio de manera tradicional o digital. Recordemos que todo ello muestra lo familiares que todavía nos son las costumbres, juegos y gustos de nuestros ancestros. (Activity III.1: Leisure and cognates)

Los alumnos escuchan de boca del profesor y luego leen un pequeño texto que describe la situación de la ciudad de Emerita Augusta: 
Activity III. 2: Listen, read and learn about leisure in Emerita Augusta.

\begin{abstract}
The Origins of Emerita Augusta and some Roman Customs...
Once upon a time, in the year $25 \mathrm{bC}$, emperor ${ }^{3}$ Augusto founded the city of Emerita Augusta as the capital of the province of Lusitania. At that time, Mérida had more than 200.000 inhabitants. (Today only 60.000) It was a very important city and public spectacles were important too. For that reason 3 public places were built to held public spectacles: The theater, the amphitheater and the circus. Along the year and for political purposes, the emperor offered public games and theater. The entrance to the spectacles was free and slaves and women were allowed to attend. There were no actresses and men played male and female characters. They wore masks. Gladiators fought at the circus against beasts and wild animals or other men. Wild animals from Asia and Africa were imported to make spectacular entertainment. Nowadays, it is known that "thumbs down" was the sign that showed that a defeated gladiator should be condemned to death; "thumbs up", that he should be forgiven. At the circus, races took place and Romans used to ride chariots. Romans had no TV or DVDs... However, Roman children also enjoyed a lot their free time. Children from poor Roman families had to work hard, but they still found some time to play. Children from rich Roman families did not have to work and had more time to play because they had slaves to do all the work in the house. They used to have pets and played with them. They also played with hoops, and flew kites. Their favorite game was Tic tac toe. They also loved walking with stilts. *Some Roman Verbs: to race, to fight against beasts, to ride a chariot, to walk with stilts, to beat...
\end{abstract}

A continuación se conecta con flechas los juegos romanos con los verbos correspondientes:

Activity III. 3: Connect Roman's favorite toys and games ${ }^{17}$.

\begin{tabular}{|l|l|}
\hline To play with & $\underline{\text { Balls }}$ \\
$\frac{\underline{\text { Board games }}}{\text { To play }}$ & $\underline{\text { Hobbyhorses }}$ \\
$\frac{\text { To ride }}{\text { Ko fly }}$ & $\underline{\text { Hoops }}$ \\
$\underline{\text { To walk with }}$ & $\underline{\text { Stilts }}$ \\
& $\underline{\text { Tic tac toe }}$ \\
& $\underline{\text { War games }}$ \\
\hline Wooden sword fights \\
\hline Dice \\
\hline
\end{tabular}

Más tarde, se dibuja un póster anunciando una carrera en un circo o una lucha de gladiadores en el anfiteatro (Activity III. 4: Draw a poster advertising a race). En conexión con esta actividad, en un ejercicio de extensión de la actividad los alumnos pueden fingir ser reporteros deportivos y retransmitir el combate o la carrera en presente o pasado simple.

Se trabaja por competencias y se evalúan subdimensiones mediante rúbrica:

17 Key: to play with balls, to play with board games, to play with hoops, to play with dice, to play war games, to play Tic tac toe, to fight with wooden sword fights, to ride hobbyhorses, to fly kites, to walk with stilts. 
III.1 (C1, C6, (C4)); III.2 (C1, C6); III.3 (C1, C6, C7), III.4 (C1, C6, C7)

\section{Fase B:}

\section{Session IV: VISIT}

Introducido el tema, se pasa a la fase B o visita.

Objetivos: El objetivo de este proyecto es utilizar el Museo Nacional de Arte Romano de Mérida (MNAR) como un aula abierta en la que los alumnos de ESO (alumnos de $3^{\circ}$ y $4^{\circ}$ en grupos de 25 acompañados de tutor/es) puedan perfeccionar sus conocimientos, destrezas y capacidades lingüísticas, históricas y artísticas a través de la gran variedad y cantidad de actividades y recursos didácticos diseñados ex profeso.

Preparación de la sesión: Ayudados de manuales que nos ayudan a relatar historias (Wright, 1997) (Moony y Holt, 1996), se cuenta el mito junto a las estatuas de los protagonistas del mito que se encuentran en la planta baja del MNAR. (Activity IV.1: We tell the myth by its protagonists). Seguidamente se lleva a cabo una actividad de 'caza del tesoro' o Scavenger Hunt donde se divide la clase en grupos de tres y se reparte una hoja de trabajo con preguntas concretas sobre aspectos culturales. Para dar emoción a la actividad, se establece un tiempo límite:

Activity IV.2: Scavenger Hunt/Ginkana ${ }^{18}$.

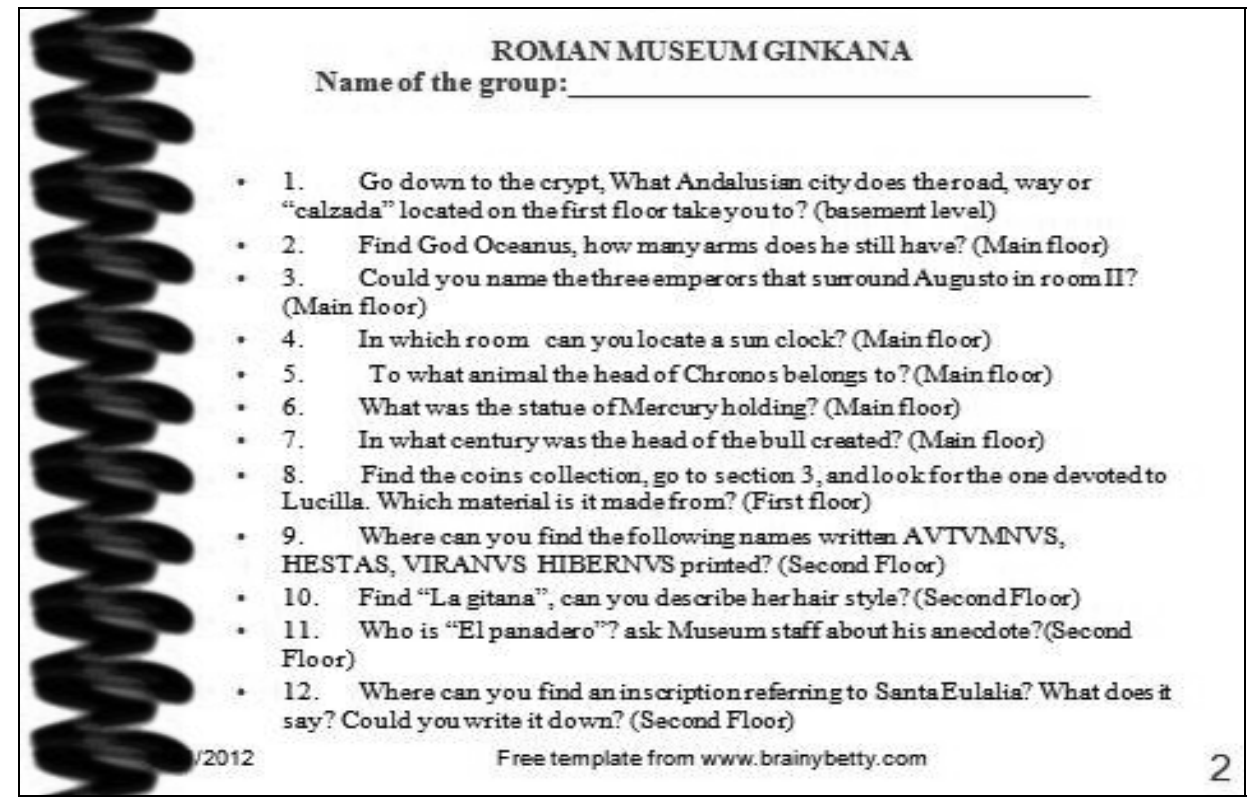

Una vez familiarizados con el museo y las piezas que contiene se procede a realizar la siguiente actividad denominada Describing ancient pics, donde se describen bustos y estatuas que hacían las veces de fotos. Cada estudiante escogerá un busto de la sala de retratos. Se

\footnotetext{
18 En la siguiente dirección se puede encontrar la distribución de las salas por niveles para preparar la visita al
} Museo Nacional de Arte Romano de Mérida (MNAR): http://museoarteromano.mcu.es/visita_virtual.html 
guía a los alumnos para que en sus descripciones usen vocabulario sencillo como "girl, boy, man, woman, young, old, middle-aged, happy, sad, worried, thoughtful, calm, curly, straight haired, bold, etc." (Activity IV.3: Describing ancient pics)

El profesor ayuda a describir sus peinados y a explicarles que, por el peinado, los arqueólogos pueden datar la fecha de los bustos y esculturas, ya que durante el Imperio Romano existieron tres tipos de peinados, uno a principios del siglo I, otro durante el resto del siglo I y un tercero en el siglo II. La moda cambiaba tan rápidamente que algunos escultores esculpían cabezas sin pelo para acoplarles pelucas. Dependiendo del nivel de los alumnos se les puede pedir que lleguen más lejos y usen vocabulario relacionado con el arte como "scene, background, position", etc.

En la última actividad se inventa una personalidad para el busto o estatua que se ha escogido (Activity IV.4: Invent a life for a portrait). Así se da por terminada la tarea, la cual se refuerza con unos ejercicios de recapitulación que ayudan en caso de que nuestros alumnos necesiten un repaso o un recordatorio posterior. Estos ejercicios se pueden conectar con cualquier punto gramatical que queramos explicar en sesiones posteriores.

Se trabaja por competencias y se evalúan subdimensiones mediante rúbrica: C7).

IV.1 (C1, C6, C5); IV.2 (C1, C5, C6, C7), IV.3 (C1, C5, C6, C7), IV.4 (C1, C5, C6,

\section{Actividades de refuerzo o extensión:}

El material que se puede elaborar pensando en la época del Imperio Romano, la ciudad de Mérida, o cualquier ciudad española con origen romano o por extensión con un museo que albergue la historia de cualquier época es muy amplio. De hecho, una segunda visita a la ciudad de Emerita llevaría a los alumnos al circo, el teatro y el anfiteatro. Otra visita llevaría a las casas romanas y templos. Teniendo como escenario cualquiera de estos monumentos se aplican los contenidos gramaticales propios del currículo de una forma más novedosa y transversal. Como ejercicio de extensión se pide a los alumnos que lleven una cámara digital al museo y que posteriormente realicen un Power Point o póster digital propio que presentan en clase.

El ejercicio estaría en consonancia con los contenidos de la clase de arte digital que es optativa en este ciclo. De este modo pueden hacer un repaso por los dioses estudiados e identificarlos con las estatuas que se encuentren en el museo y que han fotografiado.

\section{FASE C: EVALUACIÓN Y RESULTADOS}

En los últimos tiempos, la evaluación tradicional también ha evolucionando para adaptarse al MCERL y las nuevas metodologías centradas en el alumno. En este sentido, la valoración mediante rúbrica ofrece mayor adaptabilidad al aprendizaje por competencias y presenta un alto grado de adaptación a los distintos tipos de actividades de esta tarea. Tras la realización de las fases A y B, de vuelta al aula, los profesores entregaron a los alumnos una evaluación basada en rúbrica individual, cuyos resultados han derivado de los ejercicios realizados durante la tarea. La evaluación de los alumnos se realizó de manera continua. Aparte de la competencia lingüística, se tuvo en cuenta la participación activa y 
una actitud entusiasta y colaboradora Los siguientes criterios integrados en una rúbrica ${ }^{19}$, han sido adaptados a las tareas y objetivos que se proponen en este proyecto:

\begin{tabular}{|c|c|c|c|c|}
\hline & Excelente & Bueno & Regular & Precisa mejorar \\
\hline $\begin{array}{l}\text { Comprensión } \\
\text { del mito } \\
(\mathrm{C} 1, \mathrm{C} 6)\end{array}$ & $\begin{array}{l}\text { Perfecto conoci- } \\
\text { miento de idea } \\
\text { principal y deta- } \\
\text { lles secundarios }\end{array}$ & $\begin{array}{l}\text { Buen } \\
\text { conocimiento de } \\
\text { idea principal } \\
\text { y de algunas } \\
\text { secundarias }\end{array}$ & $\begin{array}{l}\text { Comprensión } \\
\text { general de idea } \\
\text { principal, pero } \\
\text { insuficiente } \\
\text { conocimiento } \\
\text { de elementos } \\
\text { más sutiles }\end{array}$ & $\begin{array}{l}\text { Escasa compren- } \\
\text { sión de la idea } \\
\text { principal y de } \\
\text { otras menos claras }\end{array}$ \\
\hline $\begin{array}{l}\text { Comprensión } \\
\text { lingüística del } \\
\text { past simple } \\
\text { (C1) }\end{array}$ & $\begin{array}{l}\text { Perfecta } \\
\text { identificación } \\
\text { y uso del past } \\
\text { simple general } \\
\text { y en contexto } \\
\text { narrativo } \\
\end{array}$ & $\begin{array}{l}\text { Identificación } \\
\text { y buen uso } \\
\text { general }\end{array}$ & $\begin{array}{l}\text { Uso autónomo } \\
\text { con alguna } \\
\text { dificultad }\end{array}$ & $\begin{array}{l}\text { Problemas al } \\
\text { corresponder } \\
\text { contenidos con el } \\
\text { texto y dificultad } \\
\text { al realizar ejer- } \\
\text { cicios }\end{array}$ \\
\hline $\begin{array}{l}\text { Trabajo en } \\
\text { grupo y partici- } \\
\text { pación activa } \\
(\mathrm{C} 5, \mathrm{C} 7)\end{array}$ & $\begin{array}{l}\text { Papel participa- } \\
\text { tivo y equiva- } \\
\text { lente. Iniciativa } \\
\text { al prestar ayuda } \\
\text { a compañeros } \\
\text { y disposición } \\
\text { para trabajar en } \\
\text { grupo }\end{array}$ & $\begin{array}{l}\text { Participación } \\
\text { igualitaria y } \\
\text { habitualmente } \\
\text { activa dentro del } \\
\text { grupo. Actitud } \\
\text { positiva en } \\
\text { tareas colabora- } \\
\text { tivas }\end{array}$ & $\begin{array}{l}\text { Participación } \\
\text { irregular e } \\
\text { insuficiente } \\
\text { contribución } \\
\text { al trabajo } \\
\text { del grupo en } \\
\text { ocasiones }\end{array}$ & $\begin{array}{l}\text { Escasa colabo- } \\
\text { ración dentro } \\
\text { del grupo y poco } \\
\text { interés en la co- } \\
\text { laboración activa } \\
\text { dentro del mismo. } \\
\text { Indiferencia }\end{array}$ \\
\hline $\begin{array}{l}\text { Uso de las TIC } \\
(\mathrm{C} 4, \mathrm{C} 7)\end{array}$ & $\begin{array}{l}\text { Excelente } \\
\text { dominio de las } \\
\text { TIC al realizar } \\
\text { ejercicios de } \\
\text { forma autónoma }\end{array}$ & $\begin{array}{l}\text { Colaboración re- } \\
\text { gular en trabajos } \\
\text { de grupo en red } \\
\text { y poca dificultad } \\
\text { al realizar ejer- } \\
\text { cicios on line }\end{array}$ & $\begin{array}{l}\text { Dificultad para } \\
\text { trabajar en red } \\
\text { y proporcionar } \\
\text { contenidos }\end{array}$ & $\begin{array}{l}\text { Poco interés en } \\
\text { uso de recursos y } \\
\text { entrega de activi- } \\
\text { dades }\end{array}$ \\
\hline
\end{tabular}

Para finalizar la tarea, se pasa un cuestionario de evaluación para poder evaluar la actividad tanto al alumnado como al profesorado.

\section{RESULTADOS}

Con el fin de comprobar la viabilidad de la experiencia se pasaron encuestas de evaluación tanto a estudiantes como a profesores implicados en la puesta en práctica de la experiencia. Además, el análisis de las rúbricas individuales demostró que los alumnos habían llegado a los objetivos marcados en menor tiempo de lo que habitualmente toma la realización de una tarea y con una actitud mucho más positiva y colaboradora. En algunos grupos, un porcentaje de alumnos tuvo algunas dificultades al realizar la tarea y en las encuestas comentaron la

\footnotetext{
19 Para diseñar rúbricas, véase la web educativa RUBISTAR: http://rubistar.4teachers.org/index. php?lang=es\&skin $=$ es
} 
dificultad de las mismas para su nivel. Dicha dificultad demuestra que, a veces, los niveles establecidos por el currículo, en los cuales se basa esta propuesta no se corresponden en su totalidad al nivel real existente. Salvando estas pequeñas contrariedades, en general, los datos de las encuestas pasadas a los alumnos y profesores implicados revelaron resultados favorables sobre el proyecto, los cuales ratifican que es enriquecedor usar aulas diferentes al aula tradicional como espacios de enseñanza/aprendizaje. En los siguientes gráficos se resumen los resultados de las encuestas realizadas a alumnos y profesores en las que se pidió a ambos que evaluaran la fase teórica y la práctica y sobre todo la compararan con las metodologías no interdisciplinares y en contextos tradicionales:

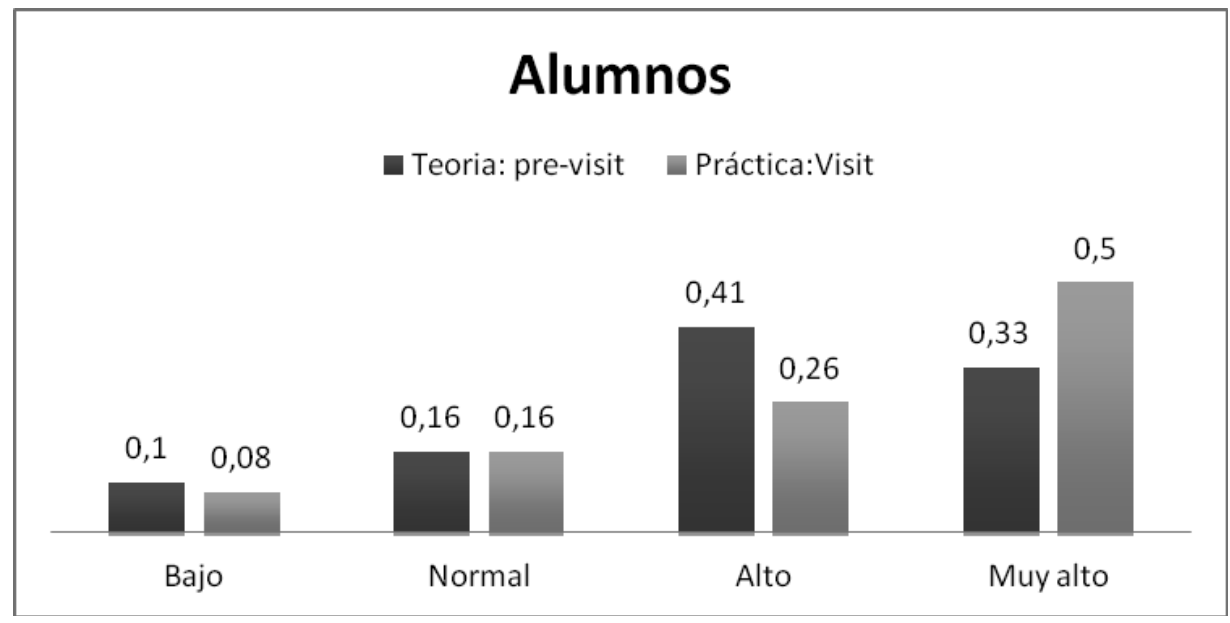

Fig. 1. Resultados de encuesta a alumnos de ESO.

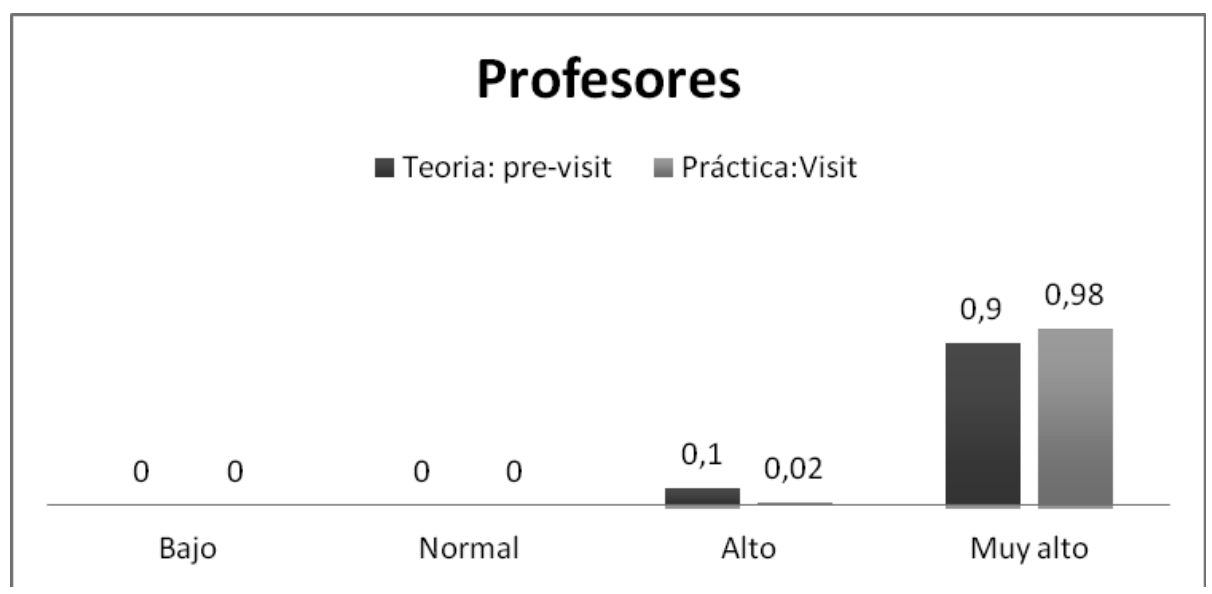

Fig. 2. Resultados de encuesta a profesores de ESO 


\section{CONCLUSIONES}

A pesar de las diferentes metodologías que se pueden aplicar al aula de ESO, las sesiones de enseñanza de inglés como segunda lengua a veces se vuelven repetitivas tanto para profesores como para alumnos. Por ello, teniendo en cuenta la interdisciplinaridad intrínseca al MCERL y la metodología AICLE, en este artículo se presenta la explotación didáctica de los museos o centros de interpretación para la enseñanza/aprendizaje de una segunda lengua aunando varias disciplinas para ofrecer al alumno un aprendizaje holístico en contextos educativos abiertos e innovadores. Tomando como ejemplo el Museo nacional de Arte Romano de Mérida, se llevó a cabo la actividad descrita que resultó bastante interesante a los grupos de alumnos de $3^{\circ}-4^{\circ}$ de ESO que se implicaron en el proyecto titulado "Teaching English through Art: Emerita Augusta as a Didactic Resource". Para que este ejercicio motivador, que ofrece la colaboración entre áreas y propone la conexión con instituciones culturales, pueda realizarse por cualquier docente interesado en sacar partido a los diferentes museos y monumentos pertenecientes al rico patrimonio histórico artístico español y universal se ha creado un blog para hacer visibles los materiales generados exclusivamente para ello ${ }^{20}$.

\section{REFERENCIAS BIBLIOGRÁFICAS}

\section{ARTCYCLOPEDIA.}

http://www.artcyclopedia.com (último acceso 9 de septiembre 2012)

Banco de Imágenes y Sonidos del Ministerio de Educación, Cultura y Deporte.

http://recursostic.educacion.es/bancoimagenes/web/ (último acceso 9 de septiembre 2012)

British BroAdcasting CoRPORATION (BBC). http://www.bbc.co.uk/schools/ primaryhistory/romans/city_of_rome/ (último acceso 9 de septiembre 2012)

BRITISH LIBRARY.

http://www.bl.uk/literatureincontext (último acceso 9 de septiembre 2012)

CARTER, R. 1986. "Linguistic Models, Language, and Literariness: Study Strategies in the Teaching of Literature to Foreign Students." Literature and Language Teaching. Eds. C. J. Brumfit y R. A. Carter. Oxford: Oxford University Press. 110-132.

Clip ART EtC.

http:/etc.usf.edu/clipart/galleries/Arts/roman_ornament.php (último acceso 9 de septiembre 2012)

Coll, C. 2008. Las competencias básicas en educación. Madrid: Alianza editorial.

Council of Europe. 2001. Common European Framework of Reference for Languages: Learning, Teaching, Assessment. Strasbourg: Council of Europe.

\footnotetext{
20 Por favor, si utiliza información extraída de este blog cítela adecuadamente.
} 
Delicado Puerto, G. 2009. "Taller de español a través de la literatura y cultura medievales". El profesor de español LE-L2: Actas del XIX Congreso Internacional de la Asociación para la Enseñanza del Español como Lengua Extranjera (ASELE). Ed. A. Barrientos Clavero. Vol. 2. Cáceres: Universidad de Extremadura. 929-943.

Doyle, D. 2012. “Teaching Mythology: Gods and Heroes.” Yale University: Yale-New Haven Teacher Institute. 25 Marzo.

http://www.yale.edu/ynhti/curriculum/units/1983/2/83.02.06.x.html

Etymological Dictionary of Classical Mythology. http://library.oakland. edu/information/people/personal/kraemer/edcm/index.html (último acceso 9 de septiembre 2012)

GARDNER, H. 1999. Intelligence Reframed: Multiple Intelligences for the 21st Century. New York: Basic Books.

.2004. Changing minds: The Art and Science of Changing our Own and Other People's Minds. Boston: Harvard Business School Press.

Gardner, J. 1993. Roman Myths. Austin: University of Texas Press.

HeIN, G. E. 1998. Learning in the Museum. London: Routledge.

Hooper-Greenhill, E. 2007. Museums and Education. Purpose, Pedagogy, Performance. London: Routledge.

LEARNING ENGLISH IN MuSEUMS.

http://eslinthemuseum.blogspot.com.es/ (último acceso 9 de septiembre 2012)

KNOWLes, L. 1982. Teaching and Reading. Londres: National Council on Industrial Language Training.

Moony, B. y Holt, D. 1996. The Storyteller's Guide. Little Rock: August House Publishers.

Museo Nacional de Arte Romano de Mérida (MNAR).

http://museoarteromano.mcu.es/visita_virtual.html (último acceso 9 de septiembre 2012)

MUSEUM OF LONDON. http://www.museumoflondon.org.uk/learning/features facts/ digging/ (último acceso 9 de septiembre 2012)

Nash, R. 1999. Dictionary of Spanish Cognates Thematically Organized. Sylmar, CA: NTC.

ONLINE ENCYCLOPEDIA OF ROMAN EMPERORS.

http://www.roman-emperors.org./alphin.htm (último acceso 9 de septiembre 2012)

REAL DECRETO 83/2007, de 24 de abril. DOE 05/05/2007 $n^{\circ} 51$ por el que se establece el Currículo de Educación Secundaria Obligatoria para la Comunidad Autónoma de Extremadura, Junta de Extremadura, Consejería de Educación. 7980-8152. http:// doe.juntaex.es/pdfs/doe/2007/510o/07040092.pdf 
REID, J. M. 1995. “Learning Styles: Issues and Answers”. Learning Styles in the ESL/ EFL Classroom. Boston: Heinle \& Heinle Publishers. 3-34.

ROMAN MYTHOLOGY FOR KIDS.

http://rome.mrdonn.org/myths.html (último acceso 9 de septiembre 2012)

RUBISTAR.

http://rubistar.4teachers.org/index.php?lang=es\&skin=es (último acceso 9 de septiembre 2012)

SAVvidou, C. "An Integrated Approach to Teaching Literature in the EFL Classroom." The Internet TESL Journal 10.12. (Dec. 2004).

http://iteslj.org/Techniques/Savvidou-Literature.html, Feb. 2012

Teaching Outside the Classroom.

http://www.teachingoutsidetheclassroom.com/ (último acceso 9 de septiembre 2012)

Web English Teacher.

http://www.webenglishteacher.com/myth.html (último acceso 9 de septiembre 2012)

Wright, A. 1997. Storytelling with Children. Oxford: Oxford University Press. 


\section{Please use this identifier to cite or link to this item:}

http://hdl. handle. net/10835/2087

Full metadata record

DC Field

Value

Language

dc.contributor.author Delicado Puerto, Gemma

dc.date.accessioned 2013-04-04T19:01:13Z

dc.date.available 2013-04-04T19:01: $13 Z$

dc.date.issued 2012

dc.identifier.issn 1578-3820

dc.identifier.uri http://hdl. handle.net/10835/2087

dc.description.abstract Esta tarea interdisciplinar muestra el potencial interpretación como aulas abiertas para enseñanza/aprendizaje de lenguas y como elemento motivador para alumnado y profesorado. Como ejemplo práctico se presenta la explotación didáctica de un mito clásico, que funciona como antesala a la visita a Emerita Augusta (Mérida, España). Asimismo, se muestran ejercicios que tienen en cuenta competencias básicas y sus indicadores de evaluación. En defi nitiva, el proyecto se plantea para acercarse al arte y a la enseñanza de inglés como segunda lengua de forma novedosa, usando espacios fuera del aula tradicional y en colaboración con instituciones museísticas.

dc.publisher Universidad de Almería.

es_ES

dc.source Odisea : Revista de Estudios Ingleses. Número es_ES

13, Enero-Diciembre 2012

dc.subject Arte

es_ES

dc.subject AICLE

es_ES

dc.subject $\mathrm{TIC}$

es_ES

dc.subject Historia

es_ES

dc.subject Motivación

es_ES

dc.subject Museo

es_ES 


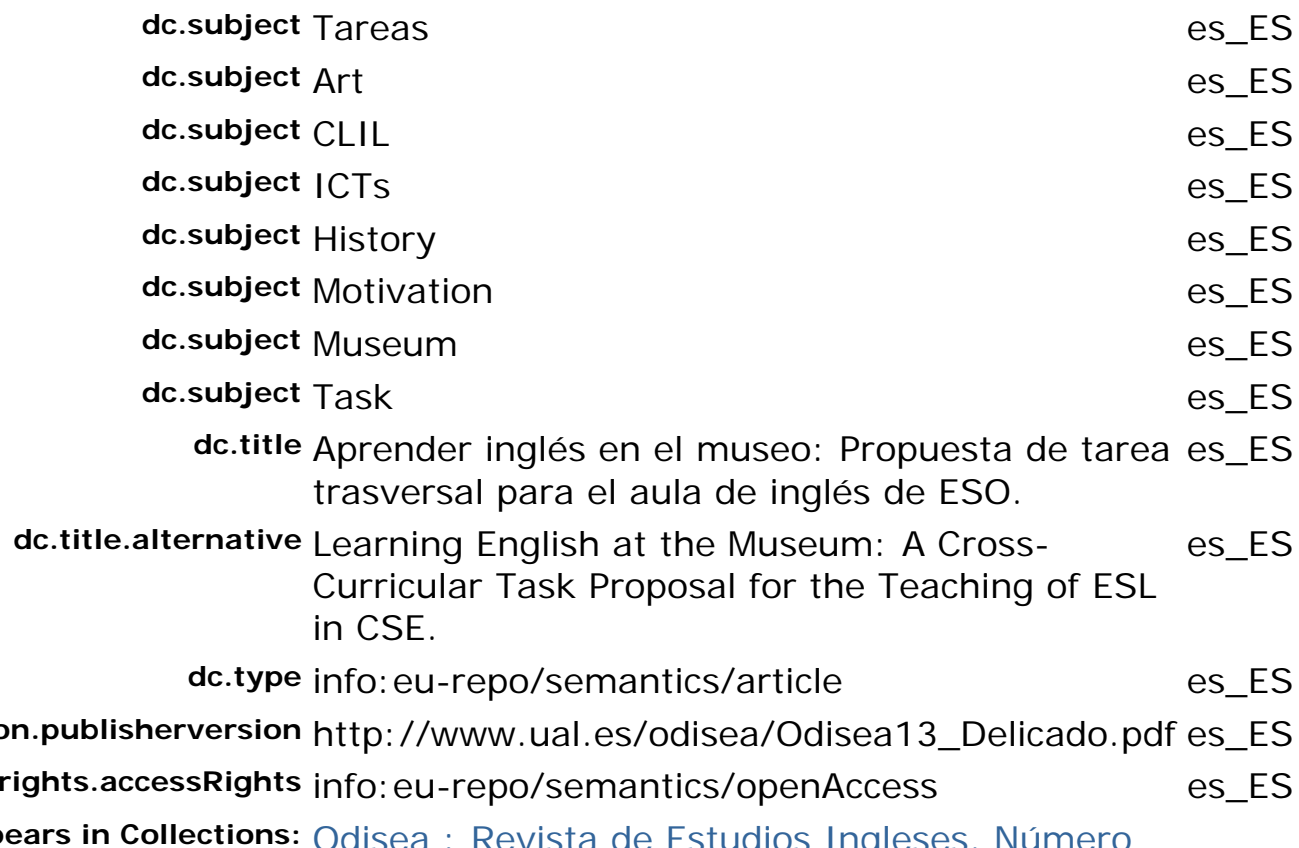
13, Enero-Diciembre 2012 